\title{
Meaning and Follow Up of Positive Fictional Decisions According to the Government Administration Law
}

\author{
Syamsir Syamsu', Muhammad Alifian Geraldi Fauzi ${ }^{2}$
}

${ }^{I}$ Faculty of Law, Universitas Lampung, Indonesia, email:syamsir.syamsu@fh.unila.ac.id

${ }^{2}$ Faculty of Law, Universitas Lampung, Indonesia, email:alifiangeraldi09@gmail.com

Submitted: October 21, 2020; Reviewed: November 30, 2020; Accepted: December 15, 2020

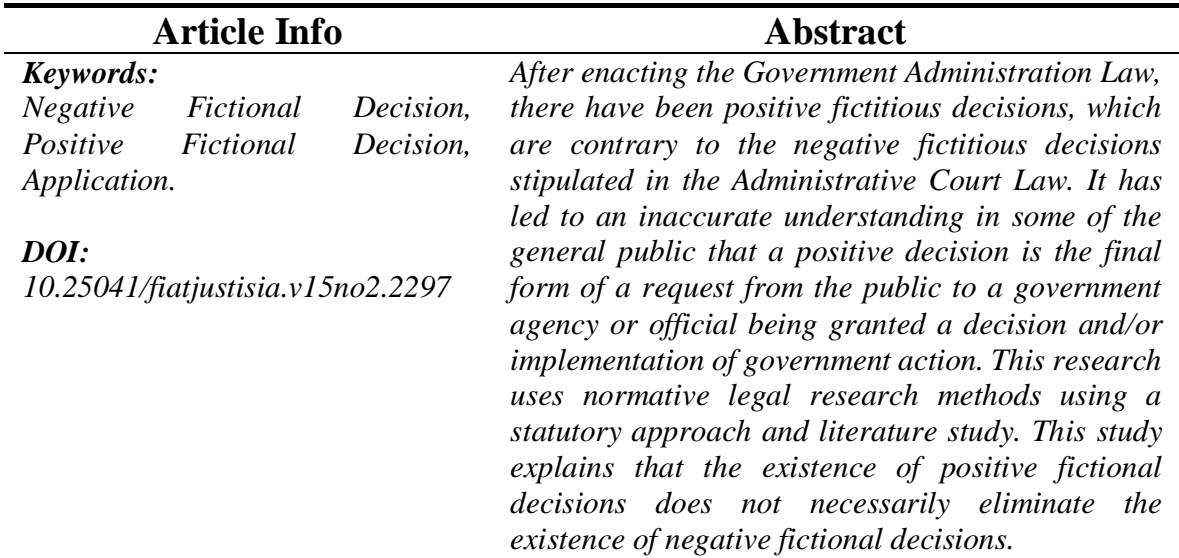

\section{A. Introduction}

After enacting Law Number 30 of 2014 concerning Government Administration (UU AP) on October 17, 2014, since then there has been a momentum of a paradigm shift in governance in Indonesia. ${ }^{1}$ The AP Law is an enlightening milestone for government and citizens in bureaucratic reform based on public services with the hope of public information disclosure and government responsibility to effectively and efficiently serve the public. ${ }^{2}$ This law contains the types of authority for attribution, delegation and mandate,

\footnotetext{
${ }^{1}$ M. Yusuf Leman, "Fungsi Undang-Undang Nomor 30 Tahun 2014 Tentang Administrasi Pemerintahan Terhadap Kualitas Penyelenggaraan Pemerintahan Di Indonesia”, Pelita - Jurnal Penelitian dan Karya Ilmiah 14, no. 1 (2019): 97-113, 106, DOI: 10.33592/pelita.Vol19.Iss1.70.

2 Solechan, "Asas-Asas Umum Pemerintahan yang Baik dalam Pelayanan Publik", Adminitrative Law \& Governance Journal 2, no. 3, (2019): 541-557, 549, DOI: 10.14710/alj.v2i3.541-557.
} 
clarity of responsibility for authority so that there is clarity of responsibility and accountability for the exercise of authority. ${ }^{3}$

The AP Law's presence has brought major changes in the configuration of the procedural law for the state administrative court. ${ }^{4}$ The changes were caused, among others, by the existence of new legal norms, hereinafter referred to as positive fictitious decisions. Meanwhile, according to Law Number 5 Year 1986 concerning State Administrative Courts (Administrative Court Law), there is a legal norm known as negative fictitious decisions. ${ }^{5}$ Of course, this raises new problems related to the existence of negative fictitious decisions according to the Administrative Law after the enactment of the AP Law as well as the meaning and follow-up of positive fictional decisions according to the AP Law.

In the context of the Administrative Court Law, if the government administration does not implement or respond to what has become its obligation when citizens apply for public services to it, legally, the application is not implemented, or the response is considered as a rejection. ${ }^{6}$ The failure to carry out these obligations is because intentionally or unintentionally understood as a silent attitude which implicitly means the same as refusing to issue the requested decision. The silence of a government official who accepts a request from the community is equated with a written decision even though physically the decision never existed (fictitious), and the silence equivalent to a written decision is deemed to contain rejection of the application submitted by the community (negative). So that such a decision is called a fictitious negative decision. ${ }^{7}$

The context of the AP Law, if the government administration does not implement or respond when citizens submit a request for public services to him, legally, the request is not implemented or the response is considered as an agreement so that it is contrary to the principles or legal principles previously adhered to in the Administrative Court Law. Based on the Law on Government Administration, a positive fictitious decision is the government's

\footnotetext{
${ }^{3}$ Andhika Satya Pratama, Dwi Poernomo, Henny Juliani, "Kajian Yuridis Terhadap Penerapan Asas Pelayanan Yang Baik Berdasarkan Pasal 10 Undang-Undang Nomor 30 Tahun 2014 Tentang Administrasi Pemerintahan di Pemerintah Kota Semarang", Diponegoro Law Review 5, no. 2, (2016): 1-14, 2.

${ }^{4}$ Francisca Romana Harjiyatni, Suswoto, "Implikasi Undang-Undang Nomor 30 Tahun 2014 tentang Administrasi Pemerintahan terhadap Fungsi Peradilan Tata Usaha Negara", Jurnal Hukum Ius Quia Iustum 24, no. 4 (2017): 601-624, 604, DOI: 10.20885/iustum.vol24.iss4.art5.

${ }^{5}$ Budiamin Rodding, "Keputusan Fiktif Negatif dan Fiktif Positif Dalam Peningkatan Kualitas Pelayanan Publik", Tanjungpura Law Journal 1, no. 1, (2017): 26-37, 26, DOI: 10.26418/tlj.v1i1.18328.

${ }^{6}$ Simanjuntak, Enrico, Prosedur Pengadilan Tata Usaha Negara (Jakarta: Sinar Grafika, 2018), 144 .

${ }^{7}$ Indroharto, Upaya Pemahaman UU Peradilan Tata Usaha Negara (Jakarta: Pustaka Sinar Harapan, 1991), 125.
} 
silence. ${ }^{8}$ Another meaning of positive fictitious terms is used and developed from a situation when the government administration authority is silent, not serving (administrative inaction) or not being responsive (delaying services) as it should be for a citizen request submitted to it. ${ }^{9}$

The concept of positive fictitious decisions in the AP Law is very different from the negative fictitious decisions in the Administrative Court Law. ${ }^{10}$ In Article 3, The Law on State Administrative Courts regulates negative fictitious decisions, namely if a State Administration Agency or Officer does not issue the requested decision while the time period has passed, then the state administrative body or official is deemed to have refused to issue the decision. ${ }^{11}$ Against the fictitious negative decision according to the state administrative law and filing a lawsuit, with the main claim obliging the defendant (state administrative body/official) to issue a decision as requested by the plaintiff (a person or civil legal entity). Whereas in the concept of a positive fictitious decision, the applicant does not automatically get what he/she is petitioning but first applies to the state administrative court to decide on the dispute over the positive fictitious decision.

Moving on to the description above, the author will discuss the meaning and follow-up of positive fictitious decisions according to the government administration law. This study is important to provide a correct understanding to the public about the existence of negative fictitious decisions according to the Administrative Law after the enactment of the AP Law and to understand the meaning and follow-up process of positive fictitious decisions according to the AP Law. The problem formulations to be discussed in this study are:

1. How is a fictitious negative decision according to the Administrative Law after the enactment of the AP Law?

2. What is the meaning and the follow-up process of a fictitious positive decision according to the AP Law?

This study uses a normative juridical research method by assessing the applicable laws and regulations (Law Number 30 of 2014 concerning Government Administration, Law Number 5 of 1986 concerning State Administrative Courts, Law 9 of 2004 concerning Amendments. First, on Law Number 5 of 1986 concerning State Administrative Courts and Law Number

\footnotetext{
${ }^{8}$ Erlin Triartha Yuliani, "Perbandingan Antara Konsep Fiktif Negatif Dalam UU 5 Tahun 1986 Tentang Peradilan Tata Usaha Negara Dengan Konsep Fiktif Positif dalam UU 30 Tahun 2014 Tentang Administrasi Pemerintahan", Jurnal Komunikasi Hukum (JKH) Universitas Pendidikan Ganesha 6, no. 1 (2020): 64-82, 64, DOI: 10.23887/jkh.v6i1.23441.

${ }^{9}$ Simanjuntak, Enrico, Op.Cit., 145

${ }^{10}$ M. Aschari, Fransisca Romana Harjiyatni, "Kajian Tentang Kompetensi Absolut Peradilan Tata Usahanegara Dalam Menyelesaikan Sengketa Keputusan Fiktif Positif", Jurnal Kajian Hukum 2, no. 1 (2017): 25-57, 40.

${ }^{11}$ Ahmad, "Konsep Fiktif Positif: Penerapannya Di Pengadilan Tata Usaha Negara", Jurnal Hukum Replik 5, no. 2 (2017): 141-156, 148, DOI: 10.31000/jhr.v5i2.923.
} 
51 of 2009 concerning the Second Amendment to Law Number 5 of 1986 concerning State Administrative Courts and literature studies to extract information from various books, journals, and other legal materials.

\section{B. Discussion}

\section{The existence of negative fictitious decisions according to the Administrative Court Law after the enactment of the AP Law.}

The object of a lawsuit in the state administrative court's procedural law is a state administrative decision. ${ }^{12}$ However, it is also known that the object of a lawsuit is in the form of a negative fictitious decision filed by a person or civil legal entity against the silence of a state administrative body or official who does not answer or respond to a request submitted by a person or civil legal entity to him. Submitting a lawsuit to the state administrative court aims to provide legal protection for the community and provide legal certainty. Positive fictitious decisions constitute regimes AP Law, and negative fictitious decisions constitute regimes administrative court law.

Article 3 of the Administrative Law basically stipulates that if a state administrative body or official does not issue a decision, while it is their obligation, then it is the same as a state administrative decision and the state administrative body or official has refused to issue the decision that someone has requested or civil legal entities. So from the provisions of this article, the right for a person or civil legal entity to file a lawsuit against a fictitious negative decision is born. ${ }^{13}$

The provisions of Article 3 of the Administrative Court Law are further termed as a fictitious negative decision. It is said to be "fictitious", which means it shows that the state administrative decision being challenged is actually intangible or never existed. It only represents the silence of a state administrative body or official, which is considered or equated with a real written state administrative decision after passing a certain time limit. Meanwhile, it is said to be "negative", which means that the state administrative decision being challenged is deemed to contain the rejection of the state administrative body or official against an application that has been submitted by a person or a civil legal entity. If the state administrative agency or official does not issue a decision (keep silent),

Every state administrative body or official acting as a public service provider is obliged to serve every request that he receives from the public. Suppose the state administrative body or official neglects its obligations. In

\footnotetext{
${ }^{12}$ Ridwan HR, "Beberapa Catatan tentang Peradilan Tata Usaha Negara di Indonesia", Jurnal Hukum 20, no. 9 (2002): 68-80, 70, DOI: 10.20885/iustum.vol9.iss20.art6.

${ }^{13}$ I Putu Agus Prapta Adiyasa, I Ketut Tjukup, Nyoman A. Martana, "Sikap Diam Badan Atau Pejabat Pemerintahan Sebagai Objek Gugatan Sengketa Tata Usaha Negara", Kertha Wicara 7, no. 3 (2019): 1-14, 3.
} 
that case, even though he does not do anything about the application he receives, the law considers that he has issued a state administrative decision that contains a rejection of the application. ${ }^{14}$

The enactment of the AP Law has given birth to a new legal concept in the form of a positive fictitious decision, which is very contrary to the concept of a fictitious negative decision stipulated in the Administrative Law. In the concept of a positive fictitious decision, a government official's silence is considered to have issued a decision containing the grant of an application submitted by a person or a civil legal entity. This raises the question: how is the existence of these negative fictitious decisions?

Suppose there is a conflict of legal norms between two equivalent regulations in the science of law. In that case, it is returned to the principle of legal preference to determine which legal norms should be enforced as positive law. However, according to the author's opinion, it is not appropriate to apply the principle of legal preference in this context. Because the Government Administration Law is an umbrella act that has a position as material law in the state administrative court, while the State Administrative Court Law is located as formal law / procedural law in the state administrative court, then it is not appropriate to position the Government Administration Law as a lex generalis and the State Administrative Court Law as a lex specialis.

In normative juridical terms, the legal norms regarding negative fictitious decisions according to the Administrative Court Law still exist (exist) because they have never been revoked or declared invalid so that the legal norms regarding negative fictitious decisions are still valid and it is still possible for a person or civil legal entity to file a proposal. The lawsuit in state administrative court.

According to the author's opinion, this must be left up to the will of the person or civil legal entity that will file in relation to the birth of new legal norms in the form of positive fictitious decisions according to the AP Law an objection to the court. Here there is a choice of law for a person or civil legal entity to resolve the problem. Will he file a lawsuit against a fictitious negative decision under the Administrative Law or file a petition against a fictitious positive decision under the AP Law.

From the aspect of efficiency and effectiveness of dispute resolution, the author believes that what should be taken by a person or a civil legal entity is filing a petition for a positive fictitious decision according to the AP Law, even though the right to file a lawsuit against a fictitious negative decision according to the Administrative Court Law is still open. In the future, in the revision of the Administrative Court Law, the provisions of Article 3 must be

${ }^{14}$ Budiamin Rodding, Op.Cit., 30. 
revoked or declared no longer valid to end the conflicting norms between the Administrative Court Law and the AP Law.

From the description above, it can be concluded that until now, the existence of negative fictitious decisions according to the Administrative Court Law still exists (exist), but for the efficiency and effectiveness of dispute resolution, there is a choice of law for a person or a civil legal entity. And you should prefer to settle disputes by submitting applications for fictitious positive decisions according to the AP Law.

\section{Meaning and Follow-up Process of Fictitious Positive Decisions according to the AP Law.}

Positive fictitious decisions have begun to be recognized in positive law in effect in Indonesia since the enactment of Law Number 30 of 2014 concerning Government Administration, which is contained in Article 53, which regulates that if state administrative bodies and/or officials neglect their obligations to issue decisions and/or administrative actions taken by the applicant within the period specified in the statutory regulations. Meanwhile, in the event that the statutory regulation does not specify a period, the grace period is determined for 10 working days after the complete application is received by government agencies and/or officials. ${ }^{15}$ This is known as a positive fictitious decision.

A fictitious decision means that a written decision does not exist. Silence from government administration officials is considered a decision, while positive means that government administration officials are considered to have made decisions and / or actions whose contents grant or constitute approval of applications submitted by a person or civil legal entity.

According to Enrico Simanjuntak, ${ }^{16}$ The terminology or positive fictitious term that is now becoming known in Indonesian legal literature can be said to be parallel to the meaning of the term lex silencio positive which terminologically comes from a combination of Latin (lex) and Spanish (silentio positivo) or in English legal terminology from mainland Europe in general. It is equated with the terms silent consent, fictitious approval or tacit authorization, whereas in the common law tradition, it can be identified with a more general concept, namely administration inaction, which does not specifically distinguish the meaning between administration omission and administrative silence. Silence, which is interpreted as an agreement, is identical to one of the maxims of law in ancient Rome: qui tacet consentire videtur (silence implies consent).

Even in a fictitious positive decision, the applicant does not automatically receive the result of his application but must first submit an application to the State Administrative Court to obtain a decision on acceptance of the

\footnotetext{
${ }^{15}$ Article 53 of Law Number 30 of 2014 concerning Government Administration.

${ }^{16}$ Simanjuntak, Enrico, Loc.Cit.
} 
application. The court is obliged to decide the application no later than 21 working days from the time the application is submitted. The court decision is final and binding, there is no other remedy. ${ }^{17}$ Government agencies and / or officials are required to make a decision to implement the decision of the State Administrative Court not later than 5 working days after the Court decision is stipulated. ${ }^{18}$

Positive fictitious decisions are an indirect effect of the globalization era. International economic competition forces all countries to increase development in their countries to grow rapidly. The government and administrative officials play an important role in the development process. If administrative officials are not cooperative in carrying out their duties, then this will undoubtedly hamper the licensing process. Therefore, the law has an important role here in bringing order to government administration. Suppose a dispute occurs due to the negligence of an administrative official. In that case, the law must be enforced and possible and fairly to be able to provide justice, benefit, and legal certainty for justice seekers who need it. ${ }^{19}$

The enthusiasm that can be captured from the makers of Law Number 30 of 2014 concerning Government Administration, there is a strong desire to create good and responsive government in the context of public services by providing the widest possible access for citizens to public services and increasing the responsibility of administrative officials government to be more responsive in taking attitudes or decisions about requests submitted by citizens.

This is reflected in the existence of a new legal term known as a positive fictitious decision, where it can be interpreted that the makers of Law Number 30 of 2014 concerning Government Administration wish to create officials of government administration officials who are responsive to requests submitted by citizens. Therefore, the formulation of Article 53 of Law Number 30 of 2014 concerning Government Administration regulates a certain grace period for government agencies and/or officials to make government decisions and/or actions calculated from the time the application is received completely and if it passes that time. Government agencies and/or officials do not respond to or take a position on the application submitted to him, so he is "considered" to have issued a fictitious positive decision.

From the above formulation, it can create an impression in the minds of the general public that, for requests that are not responded to or answered by

\footnotetext{
${ }^{17}$ Wahyunadi, Yodi Martono, Kompetensi PTUN Setelah Berlakunya Undang-Undang Nomor 30 Tahun 2014 tentang Administrasi Pemerintahan (Jakarta: Anugrah Utama Raharja, 2018), 201.

${ }^{18}$ Ibid.

${ }^{19}$ Anggita Doramia Lumbunraja, "Peran Hakim PTUN dalam Penyelesaian Sengketa Putusan Positif Fiksi", Administrative Law \& Governance Journal 2, no. 4 (2019): 677-682, 682, DOI: 10.14710/alj.v2i4.677-685
} 
government agencies and/or officials, the requests submitted by community members will be granted automatically. It is this understanding that needs to be straightened out, that with a positive fictitious decision it cannot be interpreted as a form of approval from government agencies and / or officials or that requests submitted by citizens are granted, because in the provisions of Article 53 of the AP Law there is a phrase "deemed" granted. .

The process of resolving positive fictitious decision disputes in the state administrative court has a different procedural procedure from the process for resolving state administrative disputes as regulated in the Administrative Court Law. Procedure for proceedings for cases of positive fictitious decisions are regulated in Perma Number 8 of 2017 concerning Procedure Guidelines for Obtaining Decisions on Acceptance of Applications to Obtain Decisions and/or Actions of Government Agencies or Officials. ${ }^{20}$

The party in the fictitious positive petition is the petitioner and involves other parties, namely government agencies or officials. The applicant is a party whose application is deemed legally granted due to the non-stipulation of a decision and/or non-action by government agencies and/or officials and therefore submits a request to the competent court to obtain a decision on acceptance of the application. ${ }^{21}$ And the respondent is a government agency and/or official who has an obligation to make decisions and/or take actions as intended in the applicant's petition. ${ }^{22}$ The Petitioner submits a petition against a fictitious positive decision to the state administrative court covering the jurisdiction of the respondent's domicile. If the defendant's position is outside the country, the application is filed at the Jakarta State Administrative Court. ${ }^{23}$

In the process of examining the petition for a positive fictitious decision at the state administrative court, the main problem that must be proven in court by the applicant is: "has the petition submitted by the petitioner fulfilled all the requirements for the issuance of a decision and / or the implementation of government action?". This reaffirms that the phrase considered granted cannot be interpreted as saying that the community's petition is guaranteed to be granted. Therefore, in the process of examining an application to the court, it must first be proven that the application has met all the requirements for the issuance of a decision and/or the implementation of government action.

\footnotetext{
${ }^{20}$ Ibid.

${ }^{21}$ Article 1 number 2 Perma Number 8 of 2017 concerning Guidelines for Procedures to Obtain Decisions on Acceptance of Applications to Obtain Decisions and / or Actions of Government Agencies or Officials.

${ }^{22}$ Article 1 number 3 Perma Number 8 of 2017 concerning Guidelines for Procedures to Obtain Decisions on Acceptance of Applications to Obtain Decisions and / or Actions of Government Agencies or Officials

${ }^{23}$ Article 4 paragraph 2 of Perma Number 8 of 2017 concerning Guidelines for Procedures to Obtain Decisions on Acceptance of Applications to Obtain Decisions and / or Actions of Government Agencies or Officials
} 
Suppose the applicant can prove the arguments of his petition. In that case, the court will grant the petition regarding the acceptance of a positive fictitious decision, which in turn, the court will oblige the respondent to issue the decision and/or government action requested by the community. However, on the other hand, if the applicant is unable to prove his petition's arguments, his application will be rejected, and there is no obligation for government agencies and/or officials to issue government decisions and/or actions requested by members of the public.

From the description above, it can be concluded that the phrase considered granted cannot be interpreted as meaning that government agencies and/or officials have fully granted the petition. In examining the petition for a fictitious positive decision at the state administrative court, there are still several possible outputs from the court, namely the application is declared not accepted, the application is granted, the application is rejected, or the application is cancelled.

\section{Conclusion}

Starting from the above discussion description, in the opinion of the author, the following conclusions can be drawn:

1. Until now, the existence of negative fictitious decisions according to the Administrative Court Law still exists (exist), but for efficiency and effectiveness of dispute resolution, a choice of law is available for a person or a civil legal entity. And you should prefer to settle disputes through filing a petition against a fictitious positive decision according to the AP Law.

2. The phrase considered granted cannot be interpreted as meaning that the petition has been fully granted by government agencies and/or officials. In examining the petition for a fictitious positive decision at the state administrative court, there are still several possible outputs from the court, namely the application is declared not accepted, the application is granted, the application is rejected, or the application is cancelled.

Furthermore, the authors suggest that in the upcoming revision of the Administrative Court Law, harmonization of legal norms in the Administrative Law and Government Administration Laws must be carried out, one of which is that Article 3 of the Administrative provisions Court Law must be revoked or declared invalid. Because factually, it is no longer effective. So that it does not cause conflict of legal norms with the provisions of Article 53 of the Government Administration Law. 


\section{References}

Adiyasa, I Putu Agus Prapta., Tjukup, I Ketut., Martana, Nyoman A. "Sikap Diam Badan Atau Pejabat Pemerintahan Sebagai Objek Gugatan Sengketa Tata Usaha Negara", Kertha Wicara 7, no. 3, 2019: 1-14.

Ahmad. "Konsep Fiktif Positif: Penerapannya Di Pengadilan Tata Usaha Negara", Jurnal Hukum 5, no. 2, 2017: 141-156, DOI: 10.31000/jhr.v5i2.923.

Aschari, M., Harjiyatni, Fransisca Romana. "Kajian Tentang Kompetensi Absolut Peradilan Tata Usahanegara Dalam Menyelesaikan Sengketa Keputusan Fiktif Positif", Jurnal Kajian Hukum 2, no. 1, 2017: 25-57. Harjiyatni, Francisca Romana., Suswoto. "Implikasi Undang-Undang Nomor 30 Tahun 2014 tentang Administrasi Pemerintahan terhadap Fungsi Peradilan Tata Usaha Negara", Jurnal Hukum IUS QUIA IUSTUM 24, no. 4, 2017: 601-624, DOI: 10.20885/iustum.vol24.iss4.art5.

HR, Ridwan. "Beberapa Catatan tentang Peradilan Tata Usaha Negara di Indonesia". Jurnal Hukum 20, no. 9, 2002: 68-80, DOI: 10.20885/iustum.vol9.iss20.art6.

Indroharto. Upaya Pemahaman UU Peradilan Tata Usaha Negara. Jakarta: Pustaka Sinar Harapan, 1991.

Law Number 30 of 2014 concerning Government Administration.

Law Number 5 of 1986 concerning State Administrative Courts.

Leman, M. Yusuf. "Fungsi Undang-Undang Nomor 30 Tahun 2014 Tentang Administrasi Pemerintahan Terhadap Kualitas Penyelenggaraan Pemerintahan Di Indonesia". Pelita - Jurnal Penelitian dan Karya Ilmiah 14, no. 1, 2019: 97-113, DOI: 10.33592/pelita.Vol19.Iss1.70.

Lumbunraja, Anggita Doramia. "Peran Hakim PTUN dalam Penyelesaian Sengketa Putusan Positif Fiksi", Administrative Law \& Governance Journal 2, no. 4 (2019): 677-682, DOI: 10.14710/alj.v2i4.677-685.

Perma Number 8 of 2017 concerning Guidelines for Procedures to Obtain Decisions on Acceptance of Applications to Obtain Decisions and / or Actions of Government Agencies or Officials.

Pratama, Andhika Satya., Poernomo, Dwi., Juliani, Henny. "Kajian Yuridis Terhadap Penerapan Asas Pelayanan Yang Baik Berdasarkan Pasal 10 Undang-Undang Nomor 30 Tahun 2014 Tentang Administrasi Pemerintahan di Pemerintah Kota Semarang", Diponegoro Law Review 5, no. 2, 2016: 1-14.

Rodding, Budiamin. "Keputusan Fiktif Negatif dan Fiktif Positif Dalam Peningkatan Kualitas Pelayanan Publik", Tanjungpura Law Journal 1, no. 1, 2017: 26-37, DOI: 10.26418/tlj.v1i1.18328.

Simanjuntak, Enrico. Prosedur Pengadilan Tata Usaha Negara. Jakarta: Sinar Grafika, 2018. 
Solechan, "Asas-Asas Umum Pemerintahan yang Baikdalam Pelayanan Publik", Adminitrative Law \& Governance Journal 2, no. 3, 2019: 541 557, DOI: 10.14710/alj.v2i3.541-557.

Wahyunadi, Yodi Martono. Kompetensi PTUN Setelah Berlakunya UndangUndang Nomor 30 Tahun 2014 tentang Administrasi Pemerintahan. Jakarta: Anugrah Utama Raharja.

Yuliani, Erlin Triartha. "Perbandingan Antara Konsep Fiktif Negatif Dalam UU 5 Tahun 1986 Tentang Peradilan Tata Usaha Negara Dengan Konsep Fiktif Positif dalam UU 30 Tahun 2014 Tentang Administrasi Pemerintahan". Jurnal Komunikasi Hukum (JKH) Universitas Pendidikan Ganesha 6, no. 1, 2020: 64-82, DOI: 10.23887/jkh.v6i1.23441. 
